\title{
ANALISIS KUALITAS SINYAL PADA JARINGAN LONG TERM EVOLUTION (LTE) MENGGUNAKAN DATA DRIVE TEST CLUSTER
}

\author{
I Wayan Mardika ${ }^{1}$, Gede Sukadarmika ${ }^{2}$, Pande Ketut Sudiarta \\ ${ }^{1,2,3}$ Program Studi Teknik Elektro, Fakultas Teknik, Universitas Udayana \\ Email

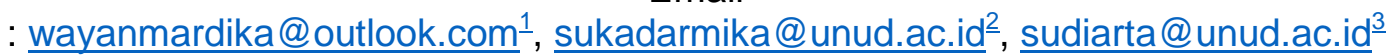

\begin{abstract}
Abstrak
Perkembangan pesat teknologi komunikasi seluler tidak terlepas dari berbagai permasalahan terutama pada kualitas sinyal. Pada area outdoor, kinerja eNodeB yang tidak optimal memungkinan terjadi kegagalan dalam melakukan komunikasi. Penelitian ini dilakukan dengan drive test pada eNodeB L_BUNDARANRENON_PL, L_AKABA_PL dan L_MYAMIN_CR untuk mendapatkan parameter kualitas sinyal pada area cluster Renon. Hasil dari drive test yang didapat akan dibandingkan dengan simulasi menggunakan software radio planning Atoll dengan model propagasi Cost-231 Hatta dan Standard Propagation Model. Dari hasil perbandingan tersebut menghasilkan nilai margin yang digunakan sebagai faktor koreksi. Hasil perbandingan didapatkan kualitas SINR, dengan menggunakan model propagasi Standard Propagation Model lebih mendekati hasil pengukuran drive test dibandingkan Cost231 Hatta. Sedangkan untuk kualitas RSRQ, kedua model propagasi memberikan hasil yang hampir sama. Dengan membandingkan antara hasil pengukuran dengan simulasi didapatkan faktor koreksi untuk SINR masing-masing model propagasi Cost-231 Hatta sebesar 6,15 dB dan Standard Propagation Model sebesar 6,11 dB. Sedangkan untuk RSRQ faktor koreksi dari kedua model propagasi sebesar $-2 \mathrm{~dB}$.
\end{abstract}

Kata Kunci: LTE, Drive test, Atoll

\begin{abstract}
The rapid development of cellular communication technology is inseparable from various problems especially on signal quality. In outdoor areas, the performance of eNodeB that is not optimal may cause communication failure. This research was conducted with the drive test on the $L \_B U N D A R A N R E N O N \_P L, L \_A K A B A \_P L$ and $L \_M Y A M I N \_C R$ to obtain signal quality parameters at Renon cluster area. The results of the drive test obtained compared to the simulation using the Atoll radio planning software with the Hatta Cost-231 propagation model and the Standard Propagation Model. From the comparison results, the margin value is used as a correction factor. The comparison results obtained based on the quality of SINR, The result of using the Standard Propagation Model is closer to the drive test measurement results than using Cost-231 Hatta. However, based on the quality of RSRQ, both propagation models yield almost the same results. Here are found that the correction factor for SINR obtained the Cost231 Hatta propagation model of $6.15 \mathrm{~dB}$ and the Standard Propagation Model model of $6.11 \mathrm{~dB}$. While for RSRQ correction factor the margin for both propagation models is $-2 d B$.
\end{abstract}

Keyword: LTE, Drive test, Atoll

\section{PENDAHULUAN}

Perkembangan pesat teknologi komunikasi seluler dimulai dari generasi pertama (1G) sampai sekarang ini generasi keempat (4G) didasarkan kepada kebutuhan masyarakat terhadap informasi dan komunikasi. Kebutuhan teknologi LTE ini merupakan tantangan bagi operator seluler (provider) untuk memberikan pelayanan terbaik bagi pengguna layanannya (user). Salah satu upaya yang dilakukan operator seluler adalah drive test.
Drive test merupakan kegiatan yang berfungsi untuk mengumpulkan data pengukuran kualitas sinyal suatu jaringan. Hasil pengukuran ini dianalisis dengan tujuan untuk meningkatkan kualitas suatu jaringan [4].

Dalam kaitannya dengan layanan yang disediakan melalui jaringan LTE terdapat beberapa hal yang mungkin masih terjadi permasalahan. Komunikasi terjadi apabila kualitas sinyal terjaga dengan baik. Pada area outdoor, kinerja eNodeB yang tidak 
optimal seperti kurangnya daya pancar dan banyaknya faktor penghalang (obstacle) pada area cakupan eNodeB. Hal ini memungkinkan MS (Mobile Station) akan mengalami pelemahan sinyal yang diterima sehingga kemungkinan terjadi kegagalan MS dalam melakukan komunikasi.

Berdasarkan permasalah tersebut, diperlukan analisis kualitas sinyal pada jaringan LTE menggunakan data drive test cluster, yaitu menganalisis kondisi eksisting eNodeB pada eNodeB L_BUNDARANRENON_PL, L_AKABA_PL, dan L_MYAMIN_CR. Parameter kualitas sinyal yang diukur adalah SINR dan RSRQ. Cara menganalisisnya adalah mengambil sample data pada antenna sectoral (Alpha, Beta, Gama) berdasarkan jarak dari ketiga eNodeB tersebut. Penelitian dengan metode ini pernah dilakukan [2], yaitu pengambilan data drive test secara single site verification (SSV) pada jaringan LTE di daerah urban, dengan parameter yang diukur adalah RSRP, RSSI dan RSSI. Dalam kaitannya dengan penelitian yang dilakukan, maka dalam penelitian ini dilakukan pengembangan dengan melakukan pengujian dengan software radio planning Attol. Selanjutnya hasil drive test yang didapat akan dibandingkan dengan simulasi Atoll dengan menggunakan model propagasi Cost-231 Hatta dan Standard Propagation Model. Dari hasil perbandingan tersebut menghasilkan margin faktor koreksi yang digunakan untuk mengganti variabel default pada software Atoll sehingga hasil simulasi dapat mendekati hasil pengukuran drive test.

\section{KAJIAN PUSTAKA}

\subsection{Teknologi Long Term Evolution (LTE)}

Long Term Evolution (LTE) adalah sebuah nama yang diberikan kepada suatu proyek dalam The Third Generation Partnership Project (3GPP) untuk mengembangkan standar komunikasi bergerak Universal Mobile Telecommunication System (UMTS) dalam mengatasi kebutuhan mendatang. Menurut standar, LTE memberikan kecepatan uplink hingga 50 megabit per detik (Mbps) dan kecepatan downlink hingga 100 Mbps [3].

\subsection{Major Parameter pada Drive Test LTE}

Parameter kualitas sinyal yang digunakan dalam drive test dijelaskan sebagai berikut.

\section{a) Signal to Interference Noise Ratio (SINR)}

SINR Merupakan perbandingan kuat sinyal dengan noise background. SINR merupakan parameter yang menunjukkan kualitas sinyal. Parameter ini menjadi acuan bagi UE dalam menentukan CQI (Channel Quality Indicator) yang akan ditransmisikan ke eNodeB. Pada teknologi $2 \mathrm{G}$ parameter ini bisa dianalogikan seperti RxQual, sedangkan 3G dianalogikan seperti EcNo [5]. Pada sistem LTE SINR dapat dihitung dengan rumus sebagai berikut.

$\operatorname{SINR}=S /(I+N)$.

Keterangan:

$S=$ Mengindikasikan daya dari sinyal yang diinginkan

$I=$ Mengindikasikan daya dari sinyal yang di ukur atau sinyal interferensi dari cell-cell yang lain

$N=$ Mengindikasikan noise background, yang berkaitan dengan perhitungan bandwidth koeffisien noise yang diterima

Standar nilai SINR ditunjukkan pada Tabel 1.

Tabel 1. Standar Nilai SINR [6]

\begin{tabular}{|c|c|c|}
\hline Warna & $\begin{array}{c}\text { Nilai SINR } \\
(\mathrm{dB})\end{array}$ & Keterangan \\
\hline & $\geq 20$ & Luar Biasa \\
\hline & $20 \mathrm{~s} / \mathrm{d} 15$ & Sangat Baik \\
\hline & $15 \mathrm{~s} / \mathrm{d} 10$ & Cukup Baik \\
\hline & $10 \mathrm{~s} / \mathrm{d} 5$ & Baik \\
\hline & $5 \mathrm{~s} / \mathrm{d} 0$ & Normal \\
\hline & $0 \mathrm{~s} / \mathrm{d}-5$ & Cukup Buruk \\
\hline & $-5 \mathrm{~s} / \mathrm{d}-10$ & Sangat Buruk \\
\hline & $<-10$ & Poor \\
\hline
\end{tabular}

b) Reference Signal Received Quality (RSRQ)

RSRQ merupakan rasio antara jumlah resource block, RSRP terhadap Received Signal Strength Indicator (RSSI). Satuan RSRQ adalah dB dan nilainya selalu negatif (karena nilai RSSI selalu lebih besar dibandingkan dengan $\mathrm{N} \times \mathrm{RSRP}$ ). RSRQ membantu sistem dalam proses handover yaitu RSRQ dapat meranking performansi kandidat sel dalam proses cell selection- 
reselection dan handover berdasarkan kualitas sinyal yang diterima. RSRQ juga dapat dikonversikan ke parameter Kualitas sinyal SINR [2]. Pada sistem LTE RSRQ dapat dihutung dengan rumus sebagai berikut.

$R S R Q=N \times R S R P / R S S I$

Keterangan:

$N=$ Number of Resource Block yang digunakan oleh OFDMA

$R S R P=$ Kuat sinyal yang diterima UE $(\mathrm{dBm})$

Standar nilai RSRQ ditunjukkan pada Tabel 2.

Tabel 2. Standar Nilai RSRQ [6]

\begin{tabular}{|c|c|c|}
\hline Warna & $\begin{array}{c}\text { Nilai RSRQ } \\
(\mathrm{dB})\end{array}$ & Keterangan \\
\hline & $\geq 5$ & Luar Biasa \\
\hline & $5 \mathrm{~s} / \mathrm{d} 2$ & Sangat Baik \\
\hline & $2 \mathrm{~s} / \mathrm{d}-1$ & Cukup Baik \\
\hline & $-1 \mathrm{~s} / \mathrm{d}-7$ & Baik \\
\hline & $-8 \mathrm{~s} / \mathrm{d}-11$ & Normal \\
\hline & $-12 \mathrm{~s} / \mathrm{d}-15$ & Cukup Buruk \\
\hline & $-16 \mathrm{~s} / \mathrm{d}-20$ & Sangat Buruk \\
\hline & $<-20$ & Poor \\
\hline
\end{tabular}

\subsection{Model Propagasi Cost-231 Hatta}

Model propagasi Cost-231 Hatta digunakan untuk mengetahui radius sel dengan range frekuensi yang digunakan adalah 1500-2000 MHz [1]. Adapun persamaan untuk menghitung redaman model propagasi adalah sebagai berikut.

$L=46.3+33.9 \log f c-13.82 \operatorname{logh} b-$

$a(h m)+(44.9-6.55 \operatorname{loghb}) \log d+C M$

$\mathrm{a}(\mathrm{hm})$ adalah faktor koreksi antena mobile yang nilainya adalah sebagai berikut.

Untuk kota kecil dan menengah,

$a(h m)=$

$(1.1 \log f c-0.7) h m-(1,56 \log f c-0.8) d B$

......................(4)

Sedangakan untuk kota besar,

$a(h m)=8,29(\log 1,54 h m)-1,1 d B$

Keterangan:

$L=$ Path Loss rata-rata (dB)

$f c=$ frekuensi $(\mathrm{MHz}) 1500 \leq f c \leq 2000 \mathrm{MHz}$

$h b=$ Tinggi antena base station $(\mathrm{m})$

$30 \leq h b \leq 200 \mathrm{~m}$

$\mathrm{hm}=$ tinggi antena mobile station $(\mathrm{m})$

$1 \leq h m \leq 10 \mathrm{~m}$ $d=$ jarak antara MS dan BS $(\mathrm{km}) 1 \leq d \leq 20$

$\mathrm{km}$

$C M=0 \mathrm{~dB}=$ for medium sized city

$3 \mathrm{~dB}=$ for metropolitan centers

2.4 Model Propagasi Standard Propagation Model

Standard Propagation Model merupakan model propagasi yang didasarkan dari model propagasi OkumuraHatta yang mendukung frekuensi yang lebih tinggi dari $1500 \mathrm{MHz}$ [1]. Adapun persamaan untuk menghitung redaman model propagasi adalah sebagai berikut.

$L=K 1+K 2 \log (d)+K 3 \log (H T x e f f)+$
$K 4+K 5(\log d) * \log H T x e f f+$
$K 6$ HRxeff + Kclutter $\ldots \ldots \ldots \ldots \ldots \ldots \ldots \ldots \ldots \ldots \ldots \ldots$

Keterangan:

$K 1=$ Frekuensi konstan $(\mathrm{dB})$

$K 2$ = Jarak redaman konstan

$d=$ Jarak antara transmitter dan receiver

$K 3, K 4=$ Koefisien koreksi dari tinggi mobile station

$K 5, K 6=$ Koefisien koreksi dari tinggi antena base station

HTxeff, HRxeff = tinggi efektif dari transmitter pada base station dan receiver pada mobile station

Kclutter $=$ Koefisien koreksi dari redaman clutter

\subsection{LTE Drive Test}

Drive test merupakan salah satu bagian pekerjaan dalam optimasi jaringan radio. Drive test bertujuan untuk mengumpulkan informasi jaringan secara real dilapangan. Informasi yang dikumpulkan merupakan kondisi Actual Radio Frekuensi (RF) di suatu eNodeB [3]. Pengambilan data drive test dapat dibagi menjadi beberapa bagian:

a) Single Site Verification (SSV)

Single Site Verification merupakan drive test untuk memverifikasi sebuah site bagus atau tidak.

b) Cluster

Cluster merpakan drive test yang mengamati stiap daerah yang terdiri dari beberapa site namun hanya untuk satu operator saja.

c) Benchmark

Benchmark merupakan drive test yang membandingkan beberapa operator dalam satu cluster.

d) Optimasi 
Optimasi merupakan bagian analisa gangguan pada site yang sudah jadi.

\subsection{Software G-Net Track Pro}

G-Net Track Pro merupakan software untuk drive test yang dapat diinstal pada handphone yang berbasis android untuk menghasilkan logfile hasil drive test yang dapat di export ke dalam aplikasi google earth [4].

\subsection{Software Radio Planning Atoll}

Attol merupakan sebuah software radio planning yang menyediakan satu set alat serta fitur yang komprehensif dan terpadu. Software ini memungkinkan user/planner untuk membuat sebuah proyek perencanaan microwave ataupun perencanaan jaringan radio bahkan melihat prediksi coverage area sebuah site dalam satu aplikasi [1].

\section{METODE PENELITIAN}

Penelitian mengenai Analisis Kualitas Sinyal Pada Jaringan Long Term Evolution (LTE) Menggunakan Data Drive Test Cluster ini dilakukan pada eNodeB L_BUNDARANRENON_PL, L_AKABA_PL, dan L_MYAMIN_CR milik PT. Indosat Ooredoo.

Gambar 1 merupakan tahapan penelitian yang dilakukan adalah study literatur, mengidentifikasi data eNodeB yang digunakan dalam simulasi selanjutnya melakukan drive test untuk mendapatkan nilai parameter kualitas SINR dan RSRQ. Kemudian melakukan perbandingan antara hasil simulasi dengan drive test, dari hasil perbandingan tersebut menghasilkan nilai margin yang digunakan sebagai faktor koreksi sehingga hasil simulasi dapat mendekati hasil pengukuran drive test.

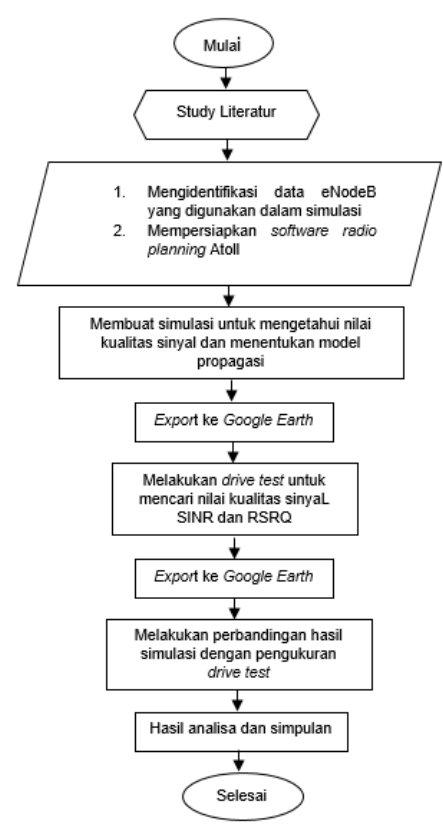

Gambar 1. Alur Analisis Penelitian

4. HASIL DAN PEMBAHASAN

Berikut merupakan hasil dan pembahasan pada penelitian ini dapat dijelaskan sebagai berikut.

\subsection{Analisis Hasil Simulasi Kualitas Sinyal di Lihat dari Parameter SINR}

Gambar 2 merupakan hasil prediksi coverage area dari Cost-231 Hatta didapat rata-rata nilai SINR sebesar $3,18 \mathrm{~dB}$ dengan cakupan yang dihasilkan $7,06 \mathrm{~km}^{2}$. Sedangkan pada Gambar 3 merupakan hasil prediksi coverage area dari standard propagation model didapat rata-rata nilai SINR sebesar 3,92 dB dengan cakupan yang dihasilkan 4,41 $\mathrm{km}^{2}$. Hal ini menunjukkan nilai kualitas SINR yang ada pada daerah perencanaan masih dalam kategori baik dan telah memenuhi standar KPI (Key Performance Indicator) PT. Indosat Ooredoo.

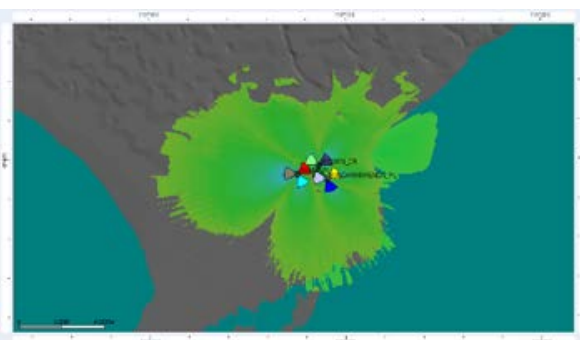

Gambar 2. Hasil Prediksi Coverage Area

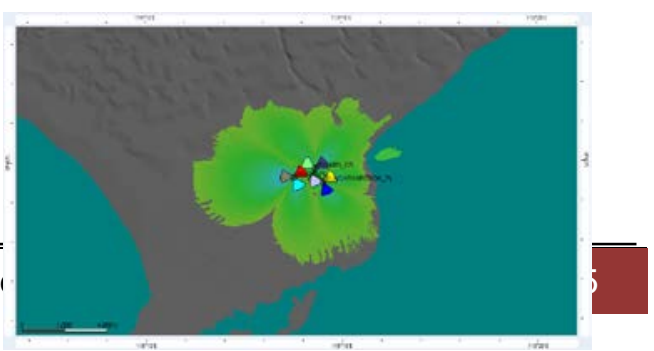


Gambar 3. Hasil Prediksi Coverage Area

\subsection{Analisis Hasil Simulasi Kualitas Sinyal di Lihat dari Parameter RSRQ}

Gambar 4 merupakan hasil prediksi coverage area dari Cost-231 Hatta didapat rata-rata nilai RSRQ sebesar $-20,53 \mathrm{~dB}$ dengan cakupan yang dihasilkan 2,45 $\mathrm{km}^{2}$. Sedangkan pada Gambar 5 merupakan hasil prediksi coverage area dari standard propagation model didapat rata-rata nilai RSRQ sebesar -20,44 dB dengan cakupan yang dihasilkan 7,63 $\mathrm{km}^{2}$. Hal ini menunjukkan nilai kualitas RSRQ yang ada pada daerah perencanaan tergolong buruk dan belum memenuhi standar KPI (Key Performance Indicator) PT. Indosat Ooredoo.

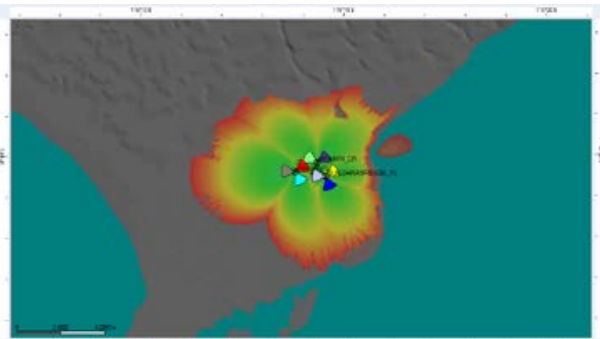

Gambar 4. Hasil Prediksi Coverage Area

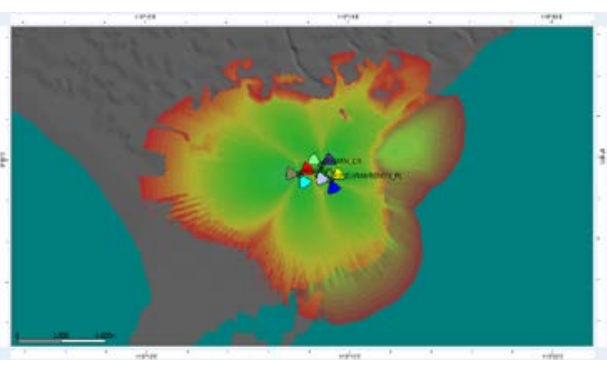

Gambar 5. Hasil Prediksi Coverage Area

\subsection{Analisis Data Hasil Drive Test eNodeB \\ L BUNDARANRENON PL}

Tabel 3 dan Tabel 4 adalah hasil drive test eNodeB L BUNDARANRENON PL. Terlihat perbedaan nilai dari masing-masing sector (SC), dengan jarak maksimal yang dapat diukur yaitu 500 meter pada SC-c. Namun pada SC-b pengukuran kualitas SINR dan RSRQ dengan jarak maksimal 400 meter, karena pada jarak yang lebih dari itu nilai SINR dan RSRQ yang didapatkan merupakan nilai dari eNodeB tetangga yaitu L_TUKADBALIAN_TB. Secara keseluruhan, rata-rata nilai SINR dan RSRQ yang didapat masih dalam kategori "Baik".

Tabel 3. Hasil Pengukuran SINR pada eNodeB L_BUNDARANRENON_PL

\begin{tabular}{|c|c|c|c|}
\hline \multirow{2}{*}{ Jarak (m) } & \multicolumn{3}{|c|}{ SINR Pengukuran (dB) } \\
\cline { 2 - 4 } & SC-a & SC-b & SC-c \\
\hline 100 & 10 & 14,8 & 13,8 \\
\hline 150 & 19,4 & 13,8 & 12,3 \\
\hline 200 & 11,4 & 12,1 & 11,6 \\
\hline 250 & 3,6 & 11,4 & 8,9 \\
\hline 300 & $-5,5$ & 9,1 & 6,9 \\
\hline 350 & 6,3 & 4,6 & 6,2 \\
\hline 400 & - & $-1,9$ & 3,1 \\
\hline 450 & - & - & 2,4 \\
\hline 500 & - & - & $-2,1$ \\
\hline
\end{tabular}

Tabel 4. Hasil Pengukuran RSRQ pada eNodeB $L$ BUNDARANRENON PL

\begin{tabular}{|c|c|c|c|}
\hline \multirow{2}{*}{ Jarak (m) } & \multicolumn{3}{|c|}{ RSRQ Pengukuran (dB) } \\
\cline { 2 - 4 } & SC-a & SC-b & SC-c \\
\hline 100 & -7 & -6 & -8 \\
\hline 150 & -6 & -7 & -7 \\
\hline 200 & -7 & -6 & -9 \\
\hline 250 & -9 & -7 & -7 \\
\hline 300 & -13 & -5 & -8 \\
\hline 350 & -8 & -8 & -8 \\
\hline 400 & - & -9 & -9 \\
\hline 450 & - & - & -9 \\
\hline 500 & - & - & -11 \\
\hline
\end{tabular}

\subsection{Analisis Data Hasil Drive Test eNodeB L_AKABA_PL}

Tabel 5 dan Tabel 6 adalah hasil drive test eNodeB L_AKABA_PL. Terlihat perbedaan nilai dari masing-masing sector (SC), dengan jarak maksimal yang dapat diukur yaitu 450 meter pada SC-a dan SCb. Namun pada SC-c pengukuran kualitas SINR dan RSRQ dengan jarak maksimal 300 meter, karena pada jarak yang lebih dari itu nilai SINR dan RSRQ yang didapatkan merupakan nilai dari eNodeB tetangga yaitu L_TUKADMELANGIT. Secara keseluruhan, rata-rata nilai SINR dan RSRQ yang didapat masih dalam kategori "Baik".

Tabel 5. Hasil Pengukuran SINR pada eNodeB L_AKABA_PL 


\begin{tabular}{|c|c|c|c|}
\hline \multirow{2}{*}{ Jarak $(\mathrm{m})$} & \multicolumn{3}{|c|}{ SINR Pengukuran $(\mathrm{dB})$} \\
\cline { 2 - 4 } & SC-a & SC-b & SC-C \\
\hline 100 & 13,5 & 17,7 & 8,4 \\
\hline 150 & 11 & 16,8 & 11 \\
\hline 200 & 7,9 & $-2,3$ & 10,8 \\
\hline 250 & 5,6 & 8,9 & 4,8 \\
\hline 300 & 6,2 & 13,4 & 3,8 \\
\hline 350 & 4,6 & 3,8 & - \\
\hline 400 & 3 & 7 & - \\
\hline 450 & 3 & 8,9 & - \\
\hline
\end{tabular}

Tabel 6. Hasil Pengukuran RSRQ pada eNodeB L_AKABA PL

\begin{tabular}{|c|c|c|c|}
\hline \multirow{2}{*}{ Jarak (m) } & \multicolumn{3}{|c|}{ RSRQ Pengukuran (dB) } \\
\cline { 2 - 4 } & SC-a & SC-b & SC-c \\
\hline 100 & -9 & -8 & -6 \\
\hline 150 & -9 & -8 & -8 \\
\hline 200 & -8 & -16 & -10 \\
\hline 250 & -10 & -10 & -10 \\
\hline 300 & -9 & -8 & -10 \\
\hline 350 & -8 & -10 & - \\
\hline 400 & -7 & -7 & - \\
\hline 450 & -8 & -9 & - \\
\hline
\end{tabular}

\subsection{Analisis Data Hasil Drive Test} eNodeB L_MYAMIN_CR

Tabel 7 dan Tabel 8 adalah hasil drive test eNodeB L_MYAMIN_CR. Terlihat perbedaan nilai dari masing-masing sector (SC), dengan jarak maksimal yang dapat diukur yaitu 500 meter pada SC-a. Secara keseluruhan, rata-rata nilai SINR dan RSRQ yang didapat masih dalam kategori "Baik".

Tabel 7. Hasil Pengukuran SINR pada eNodeB L_MYAMIN_CR

\begin{tabular}{|c|c|c|c|}
\hline \multirow{2}{*}{ Jarak (m) } & \multicolumn{3}{|c|}{ SINR Pengukuran (dB) } \\
\cline { 2 - 4 } & SC-a & SC-b & SC-C \\
\hline 100 & 19,6 & 13,6 & 8,2 \\
\hline 150 & 21,4 & 17 & 7 \\
\hline 200 & 19,7 & 9 & 8,4 \\
\hline 250 & 20,3 & 6 & 11,6 \\
\hline 300 & 16,6 & $-1,8$ & 9,1 \\
\hline 350 & $-2,8$ & 7,2 & 4 \\
\hline 400 & 12,2 & 4,4 & - \\
\hline 450 & 7 & - & - \\
\hline 500 & 4,1 & - & - \\
\hline
\end{tabular}

Tabel 8. Hasil Pengukuran RSRQ pada eNodeB L_MYAMIN_CR

\begin{tabular}{|c|c|c|c|}
\hline \multirow{2}{*}{ Jarak (m) } & \multicolumn{3}{|c|}{ RSRQ Pengukuran (dB) } \\
\cline { 2 - 4 } & SC-a & SC-b & SC-c \\
\hline 100 & -8 & -7 & -6 \\
\hline 150 & -9 & -9 & -6 \\
\hline 200 & -11 & -7 & -6 \\
\hline 250 & -8 & -9 & -6 \\
\hline 300 & -7 & -12 & -7 \\
\hline 350 & -12 & -7 & -8 \\
\hline 400 & -9 & -8 & - \\
\hline 450 & -9 & - & - \\
\hline 500 & -10 & - & - \\
\hline
\end{tabular}

\subsection{Analisis Perbandingan Hasil Pengukuran Drive Test Dengan Simulasi Atoll}

Perbandingan data hasil pengukuran drive test menggunakan G-Net Track Pro dengan hasil simulasi menggunakan software radio planning Atoll. Hasil perbandingan tersebut digunakan untuk mengetahui margin faktor koreksi dari nilai SINR dan RSRQ, yang nantinya akan digunakan untuk menentukan model propagasi yang cocok untuk diterapkan di daerah sub urban.

\subsubsection{Analisis Perbandingan SINR eNodeB}

L BUNDARANRENON PL

Gambar 6 menunjukkan hasil perbandingan antara pengukuran dengan simulasi pada eNodeB L_BUNDARANRENON_PL. Dari analisis yang didapat, hasil perbandingan kualitas SINR masih dalam range kategori "Baik". Tetapi ditemukan satu kondisi, yaitu pada sector-a dengan jarak 300 meter nilai SINR $-5,5 \mathrm{~dB}$ yang termasuk dalam range nilai buruk, ditunjukkan dengan garis biru. Rendahnya nilai SINR yang di dapat sectora pada jarak 300 meter ini disebabkan oleh adanya obstacle berupa gedung.

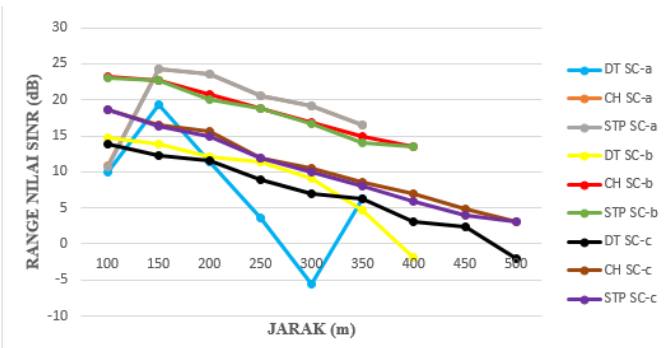


Gambar 6. Hasil Perbandingan SINR eNodeB L_BUNDARANRENON_PL

Keterangan gambar: DT (drive test), $\mathrm{CH}$ (cost-231 Hatta), STP (Standard Propagation Model).

\subsubsection{Analisis Perbandingan SINR eNodeB L_AKABA_PL}

Gambar 7 menunjukkan hasil perbandingan antara pengukuran dengan simulasi pada eNodeB L_AKABA_PL. Dari analisis yang didapat, hasil perbandingan kualitas SINR dalam range kategori "Baik". Tetapi ditemukan satu kondisi, yaitu pada sector-b dengan jarak 200 meter nilai SINR $-2,3 \mathrm{~dB}$ yang termasuk dalam range nilai buruk, ditunjukkan dengan garis kuning. Rendahnya nilai SINR yang di dapat sectorb pada jarak 200 meter ini disebabkan oleh adanya obstacle berupa gedung.

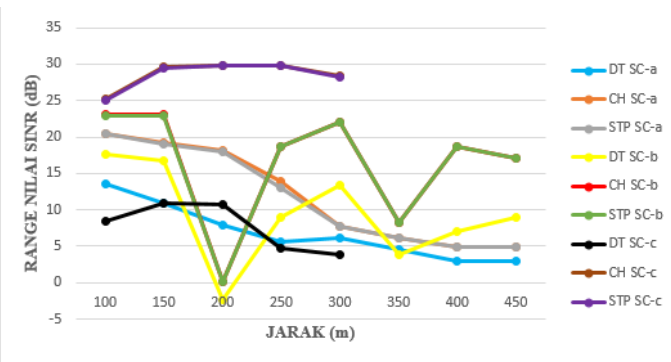

Gambar 7. Hasil Perbandingan SINR eNodeB L_AKABA_PL

\subsubsection{Analisis Perbandingan SINR eNodeB L MYAMIN CR \\ Gambar 8 menunjukkan hasil} perbandingan antara pengukuran dengan simulasi pada eNodeB L MYAMIN CR. Dari analisis yang didapat, hasil perbandingan kualitas SINR dalam range kategori "Baik". Tetapi ditemukan satu kondisi, yaitu pada sector-a dan sector-b dengan jarak 350 meter dan 300 meter nilai SINR -2,8 dB dan -1,8 dB yang termasuk dalam range nilai buruk, ditunjukkan dengan garis biru dan kuning. Rendahnya nilai SINR yang di dapat sector-a dan sector-b pada jarak 350 meter dan 300 meter ini disebabkan oleh adanya obstacle berupa perumahan.

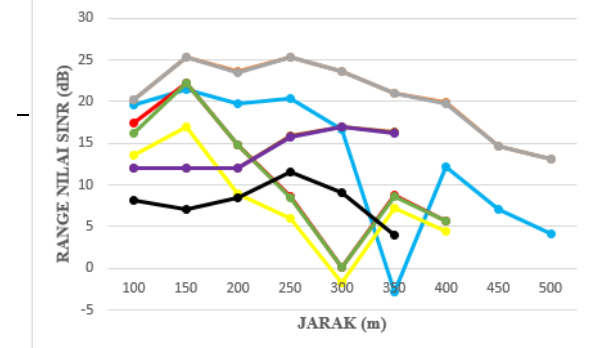

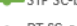

$\rightarrow-0$ DT SC-a

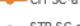

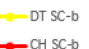
2 STs Sce Ketut Sudiarta
Gambar 8. Hasil Perbandingan SINR eNodeB L_MYAMIN_CR

Berdasarkan analisis perbandingan nilai SINR yang didapat dari eNodeB L_BUNDARANRENON_PL, L_AKABA_PL, dān L_MYAMIN_CR. Nilai faktor koreksi yang didapat dengan menggunakan model propagasi Standard Propagation Model lebih mendekati dengan hasil pengukuran drive test dibandingkan dengan model Cost-231 Hatta. Hal ini menunjukkan propagasi Standard Propagation Model lebih cocok diterapkan di daerah Denpasar dengan kategori daerah Sub Urban.

\subsubsection{Analisis Perbandingan RSRQ eNodeB L_BUNDARANRENON_PL}

Gambar 9 menunjukkan hasil perbandingan antara pengukuran dengan simulasi pada eNodeB L_BUNDARANRENON_PL. Dari analisis yang didapat, hasil perbandingan kualitas RSRQ dalam range kategori "Baik". Tetapi ditemukan satu kondisi, yaitu pada sector-a dengan jarak 300 meter nilai RSRQ -12 dB yang termasuk dalam range nilai buruk, ditunjukkan dengan garis biru. Rendahnya nilai RSRQ yang di dapat sector-a pada jarak 300 meter ini disebabkan oleh adanya obstacle berupa gedung. Selain disebabkan oleh obstacle, kualitas RSRQ juga dipengaruhi oleh kuat sinyal atau Reference Signal Received Power (RSRP), dengan formula sebagai berikut "semakin besar nilai RSRQ maka nilai RSRP juga akan semakin besar". Pada saat nilai RSRQ buruk, sebagai contoh pada jarak 300 meter SC-a, nilai RSRP juga buruk yaitu $-96 \mathrm{dBm}$.

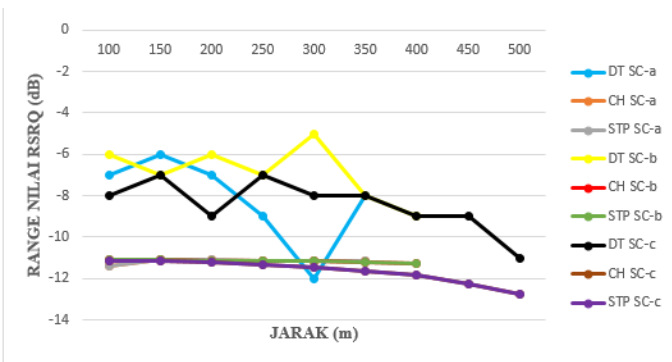


Gambar 9. Hasil Perbandingan RSRQ eNodeB L_BUNDARANRENON_PL

\subsubsection{Analisis Perbandingan RSRQ eNodeB L AKABA PL}

Gambar 10 menunjukkan hasil perbandingan antara pengukuran dengan simulasi pada eNodeB L_AKABA_PL. Dari analisis yang didapat, hasil perbandingan kualitas RSRQ dalam range kategori "Baik". Tetapi ditemukan satu kondisi, yaitu pada sector-b dengan jarak 200 meter nilai RSRQ -16 dB yang termasuk dalam range nilai buruk, ditunjukkan dengan garis kuning. Rendahnya nilai RSRQ yang di dapat sector-b pada jarak 200 meter ini disebabkan oleh adanya obstacle berupa gedung. Selain disebabkan oleh obstacle, kualitas RSRQ juga dipengaruhi oleh kuat sinyal atau Reference Signal Received Power (RSRP), dengan formula sebagai berikut "semakin besar nilai RSRQ maka nilai RSRP juga akan semakin besar". Pada saat nilai RSRQ buruk, sebagai contoh pada jarak 200 meter SC-b, nilai RSRP juga buruk yaitu $-99 \mathrm{dBm}$.

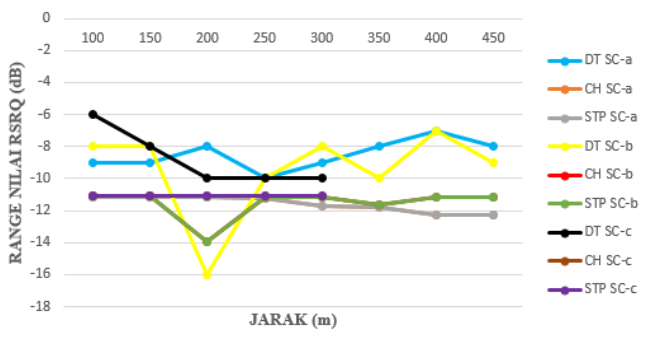

Gambar 10. Hasil Perbandingan RSRQ eNodeB L_AKABA_PL

\subsubsection{Analisis Perbandingan RSRQ eNodeB L MYAMIN CR}

Gambar 11 menunjukkan hasil perbandingan antara pengukuran dengan simulasi pada eNodeB L MYAMIN CR. Dari analisis yang didapat, hasil perbandingan kualitas RSRQ dalam range kategori "Baik". Tetapi ditemukan satu kondisi, yaitu pada sector-a dan sector-b dengan jarak 350 meter dan 300 meter nilai RSRQ -12 dB dan -12 dB yang termasuk dalam range nilai buruk, ditunjukkan dengan garis biru dan kuning. Rendahnya nilai RSRQ yang di dapat sector-a dan sector-b pada jarak 350 meter dan 300 meter ini disebabkan oleh adanya obstacle berupa perumahan. Selain disebabkan oleh obstacle, kualitas RSRQ juga dipengaruhi oleh kuat sinyal atau Reference Signal Received Power (RSRP). Dengan formula sebagai berikut "semakin besar nilai RSRQ maka nilai RSRP juga akan semakin besar". Pada saat nilai RSRQ buruk, sebagai contoh pada jarak 350 meter SC-a dan 300 meter SC-b, nilai RSRP juga buruk yaitu $-95 \mathrm{dBm}$ dan $-103 \mathrm{dBm}$.

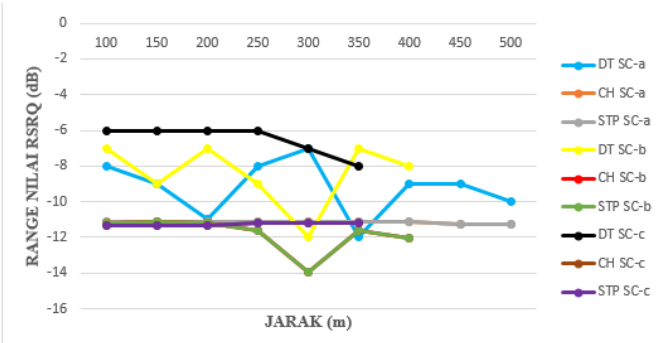

Gambar 11. Hasil Perbandingan RSRQ eNodeB L_MYAMIN_CR

\subsection{Analisis Perbandingan Kualitas SINR Sesudah Ditambahkan Faktor Koreksi}

Setelah mendapatkan margin faktor koreksi antara hasil pengukuran dengan simulasi, tahap selanjutnya yaitu memasukkan nilai faktor koreksi yang didapat dengan megganti variabel default pada Software Attol. Dengan menggunakan nilai rata-rata margin faktor koreksi yang didapat pada eNodeB L_MYAMIN_CR SCc sebesar 6,15 dB untuk Cost-231 Hatta dan 6,11 dB untuk Standard Propagation Model. Hasil perbandingan dapat dilihat pada Tabel 9.

Tabel 9. Perbandingan Setelah Ditambahkan Faktor Koreksi

\begin{tabular}{|c|c|c|c|c|c|}
\hline \multirow{3}{*}{$\begin{array}{c}\text { Jarak } \\
(\mathrm{m})\end{array}$} & \multicolumn{3}{|c|}{ eNodeB L_MYAMIN_CR SC-C } \\
\cline { 2 - 6 } & \multirow{2}{*}{$\begin{array}{c}\text { DT } \\
(\mathrm{dB})\end{array}$} & \multicolumn{2}{|c|}{$\begin{array}{c}\text { Sebelum } \\
(\mathrm{dB})\end{array}$} & \multicolumn{2}{c|}{ Sesudah } \\
\cline { 3 - 6 } & & $\mathrm{CH}$ & $\mathrm{STP}$ & $\mathrm{CH}$ & STP \\
\hline 100 & 8,2 & 3,84 & 3,83 & 3,78 & 3,75 \\
\hline 150 & 7 & 5,04 & 5,03 & 4,98 & 4,95 \\
\hline 200 & 8,4 & 3,64 & 3,63 & 3,58 & 3,55 \\
\hline 250 & 11,6 & 4,28 & 4,2 & 4,2 & 3,4 \\
\hline 300 & 9,1 & 7,87 & 7,8 & 7,85 & 7,7 \\
\hline 350 & 4 & 12,28 & 12,2 & 12 & 12 \\
\hline
\end{tabular}

Tabel 9 menunjukkan hasil perbandingan margin nilai SINR sebelum dan sesudah ditambahkan faktor koreksi. Sebagai contoh pada jarak 150 meter untuk model propagasi Cost-231 Hatta nilai SINR sebesar 5,04 dB menjadi 4,98 dB sedangkan untuk Standard Propagation Model nilai SINR sebesar 5,03 dB menjadi $4,95 \mathrm{~dB}$. Dari analisis yang didapat 
menyatakan bahwa dengan menambahkan faktor koreksi, nilai SINR akan lebih mendekati dengan hasil pengukuran dilapangan.

\subsection{Analisis Perbandingan Kualitas RSRQ Sesudah ditambahkan Faktor Koreksi}

Setelah mendapatkan margin faktor koreksi antara hasil pengukuran dengan simulasi, tahap selanjutnya yaitu memasukkan nilai faktor koreksi yang didapat dengan megganti variabel default pada Software Attol. Dengan menggunakan nilai rata-rata margin faktor koreksi yang didapat pada eNodeB L_MYAMIN_CR SCa sebesar -2 dB untuk kedua model propagasi. Hasil perbandingan dapat dilihat pada Tabel 10.

Tabel 10. Perbandingan Setelah Ditambahkan Faktor Koreksi

\begin{tabular}{|c|c|c|c|c|c|}
\hline \multirow{3}{*}{$\begin{array}{c}\text { Jarak } \\
(\mathrm{m})\end{array}$} & \multicolumn{4}{|c|}{ eNodeB L_MYAMIN_CR SC-a } \\
\cline { 2 - 6 } & \multirow{2}{*}{$\begin{array}{c}\text { DT } \\
(\mathrm{dB})\end{array}$} & \multicolumn{2}{|c|}{$\begin{array}{c}\text { Sargin RSRQ } \\
(\mathrm{dB})\end{array}$} & \multicolumn{2}{c|}{$\begin{array}{c}\text { Margin RSRQ } \\
(\mathrm{dB})\end{array}$} \\
\cline { 3 - 6 } & & $\mathrm{CH}$ & STP & $\mathrm{CH}$ & STP \\
\hline 100 & -8 & $-3,13$ & $-3,13$ & $-3,13$ & $-3,13$ \\
\hline 150 & -9 & $-2,09$ & $-2,09$ & $-2,09$ & $-2,09$ \\
\hline 200 & -11 & $-0,11$ & $-0,11$ & $-0,11$ & $-0,11$ \\
\hline 250 & -8 & $-3,12$ & $-3,12$ & $-3,12$ & $-3,12$ \\
\hline 300 & -7 & $-4,11$ & $-4,11$ & $-4,11$ & $-4,11$ \\
\hline 350 & -12 & 0,88 & 0,88 & 0,88 & 0,88 \\
\hline 400 & -9 & $-2,13$ & $-2,13$ & $-2,13$ & $-2,13$ \\
\hline 450 & -9 & $-2,23$ & $-2,23$ & $-2,23$ & $-2,23$ \\
\hline 500 & -10 & $-1,29$ & $-1,29$ & $-1,29$ & $-1,29$ \\
\hline
\end{tabular}

Tabel 10 menunjukkan hasil perbandingan margin nilai RSRQ sebelum dan sesudah ditambahkan faktor koreksi. Sebagai contoh pada jarak 100 meter untuk model propagasi Cost-231 Hatta nilai RSRQ sebesar -3,13 dB menjadi -3,13 dB sedangkan untuk Standard Propagation Model nilai RSRQ sebesar $-3,13 \mathrm{~dB}$ menjadi $-3,13 \mathrm{~dB}$. Dari analisis yang didapat menyatakan bahwa dengan menambahkan faktor koreksi, margin nilai RSRQ yang didapat tetap sama dengan hasil sebelum ditambahkan faktor koreksi.

\section{KESIMPULAN}

Hasil simulasi menggunakan software radio planning Atoll menunjukkan, SINR rata-rata yang didapat dari ketiga eNodeB masih dalam range kategori "Baik". Untuk model propagasi Cost-231 Hatta nilai SINR sebesar 3,18 dB dengan coverage area yang dihasilkan $7,06 \mathrm{~km}^{2}$. Sedangkan untuk model propagasi Standard Propagation Model nilai SINR sebesar 3,92 dB dengan coverage area yang dihasilkan $4,41 \mathrm{~km}^{2}$.

Hasil simulasi menggunakan software radio planning Atoll menunjukkan, RSRQ rata-rata yang didapat dari ketiga eNodeB termasuk dalam range kategori "Buruk". Untuk model propagasi Cost-231 Hatta nilai RSRQ sebesar $-20,53 \mathrm{~dB}$ dengan coverage area yang dihasilkan $2,45 \mathrm{~km}^{2}$. Sedangkan untuk model propagasi Standard Propagation Model nilai RSRQ sebesar $20,44 \mathrm{~dB}$ dengan coverage area yang dihasilkan $7,63 \mathrm{~km}^{2}$.

Hasil pengukuran menggunakan G-Net Track Pro menunjukkan kualitas SINR dan RSRQ dapat dikatakan masih dalam range kategori "Baik" dengan masing-masing jarak maksimal yang dapat diukur yaitu 500 meter.

Perbandingan kualitas SINR, dengan menggunakan model propagasi Standard Propagation Model lebih mendekati hasil pengukuran dilapangan dibandingkan Cost231 Hatta. Sedangkan untuk kualitas RSRQ, kedua model propagasi memberikan hasil yang hampir sama.

Hasil perbandingkan antara pengukuran dengan simulasi didapatkan hasil faktor koreksi untuk SINR masingmasing model propagasi, yaitu Model Cost231 Hatta sebesar 6,15 dB dan Standard Propagation Model sebesar 6,11 dB. Sedangkan propagasi untuk RSRQ kedua model propagasi $-2 \mathrm{~dB}$.

\section{DAFTAR PUSTAKA}

[1] Putra, T.G.A.S, Sudiarta, P.K, Diafari, I.G.A.K, Analisis Pengaruh Model Propagasi dan Perubahan Tilt Antena Terhadap Coverage Area Sistem Long Term Evolution Menggunakan Software Atoll, E-Journal Spektrum. 2015; Vol.2 No.4: 46-52.

[2] Bengawan Alfaresi, Analisa Indikator Performansi Jaringan 4G LTE (Long Term Evolution) frekuensi $1800 \mathrm{MHz}$ Terhadap Perubahan Jarak eNodeB di Daerah Urban, Jurnal Surya Energy. 2017; Vol.1 No.2: 60-70.

[3] Pramulia, I.P.D.K, Sudiarta, P.K, Sukadarmika, G, Analisis Pengaruh Jarak Antara User Equipment Dengan eNodeB Terhadap Nilai RSRP (Reference Signal Received Power) Pada Teknologi LTE $900 \mathrm{MHz}$, EJournal Spektrum. 2015; Vol.2 No.3: 24-30. 
[4] Yanuar, R, Sudiarta, P.K, Gunantara, $N$, Analisa Kualitas Sinyal Jaringan GSM Pada Menara Rooftop Dengan Membandingkan Aplikasi Metode Drive Test Antara Tems Investigation 8.0.3 Dengan G-Nettrack Pro, E-Journal Spektrum. 2015; Vol.2 No.4: 39-45.

[5] Nur Wahyu Ari Setiawan, Ir. Achmad Ali Muayyadi, M.Sc., Ph.D, Hurianti Vidyaningtyas, S.T., M.T, Optimasi Layanan Data Pada Jaringan LTE Dengan Genex Assistant di Delanggu Klaten, e-Proceeding of Engineering. 2017; Vol.4 No.3: 3532-3539.

[6] http://www.gyokovsolutions.com/manu als/gnettrackpro_manual.php, diakses tanggal 18 Desember 2018. 